\title{
STATISTICAL MAPPING AND 3-D SURFACE PLOTS IN PHYTOPLANKTON ANALYSIS OF THE BALKHASH LAKE (KAZAKHSTAN)
}

\author{
Elena KRUPA*, Sophia BARINOVA**, \\ Lyubov PONAMAREVA *** and Vyacheslav TSOY ***
}

* Republican State Enterprise on the Right of Economic Use "Institute of Zoology", Ministry of Education and Science, Science Committee, Almaty, Kazakhstan, KZ-050060, elena_krupa@mail.ru ** University of Haifa, Institute of Evolution, Mount Carmel, Abba Khoushi Avenue 199, Haifa, Israel, IL-3498838, Israel, sophia@evo.haifa.ac.il

*** "Kazakh Research Institute of Fishery” LLP, Zheltoksan Street 20, Balkhash, Kazakhstan KZ-100300, tsoy-balkhash@mail.ru

DOI: 10.1515/trser-2018-0001

KEYWORDS: phytoplankton, structure, spatial dynamics, statistics, Balkhash.

\section{ABSTRACT}

Phytoplankton of the Balkhash Lake was represented by 91 species with average abundance of 1,002.4 mln. ind. $\mathrm{m}^{-3}$ and average biomass of $0.853 \mathrm{~g} \mathrm{~m}^{-3}$ in summer 2004. Maps of spatial distribution revealed that phytoplankton abundance was confined within the nearestuary sections of the rivers. Correlation analysis and 3D Surface Plots showed that the average mass of the algal cell decreased with increased phytoplankton abundance, species richness, and Shannon Bi index values. Synchronicity of the spatial dynamics of W-Clarke and $\Delta$-Shannon values evidenced the possibility of obtaining information on the structure of communities by both calculated and graphical methods.

ZUSAMMENFASSUNG: Statistische Kartierung und 3-D Darstellung der Oberfläche in einer Phytoplanktonanalyse des Balkhash Sees (Kazakhstan).

Das Phytoplankton des Balkhash-Sees war im Sommer 2004 durch 91 Arten mit einer durchschnittlichen Häufigkeit von 1.002,4 Millionen Individuen pro $\mathrm{m}^{-3}$ und einer durchschnittlichen Biomasse von 0,853 $\mathrm{g}_{\text {pro }}{ }^{-3}$ vertreten. Karten der räumlichen Verteilung zeigten, dass die Phytoplankton-Abundanz in den nahe der Mündungebereiche liegenden Abschnitten der Flüsse begrenzt war. Korrelationsanalysen und die 3-D-Oberflächen-Parzellen zeigten, dass die durchschnittliche Masse der Algen-Zellen bei anwachsender PhytoplanktonAbundanz, Artenreichtum und steigenden Werten des Shannon Bi-Index sank. Die Synchronität der räumlichen Dynamik von W-Clarke- und $\Delta$-Shannon-Werten zeigte die Möglichkeit auf, Informationen über die Struktur der Gemeinschaften sowohl aufgrund rechnerischer als auch graphischer Methoden zu erhalten.

REZUMAT: Cartografiere și parcelare de suprafaţă 3D statistice în analiza fitoplanctonului lacului Balkhash, Kazahstan.

Fitoplanctonul lacului Balkhash a fost reprezentat de 91 de specii cu abundența medie $1.002,4$ mln. ind. $\mathrm{m}^{-3}$ și o biomasă medie de $0,853 \mathrm{~g} \mathrm{~m}^{-3}$, în vara anului 2004. Hărți de distribuție spațială au arătat că abundența fitoplanctonului a fost limitată în cadrul secțiunilor în apropierea estuarului râurilor. Analiza corelațiilor și parcelarea de suprafață 3D au arătat că masa medie a celulelor algale a scăzut atunci când a crescut abundența fitoplanctonului, bogăția de specii, și valorile indicelui Shannon Bi. Sincronicitatea dinamică spațială a valorilor $\Delta$ Shannon și W-Clarke a evidențiat posibilitatea de a obține informații cu privire la structura comunităților prin metode calculate și grafice. 


\section{INTRODUCTION}

The Balkhash Lake (Figs. 1-3) is one of the largest lakes within the arid zone of Kazakhstan (Kudekov, 2002). The rivers Ili, Karatal, Aksu, and Lepsy, that flow into the lake from the south, originate in the mountains of the Tian Shan. The Uzynaral Strait divides the lake into two different parts: the Western Balkhash and the Eastern Balkhash. The Balkhash Lake features an increase of total dissolved solids (TDS) in the direction from west to east (Tarasov, 1961). Increased level of heavy metals in water and soil (Kudekov, 2002) is caused by the presence of ore deposits in the region (Mazurov, 2005) as well as anthropogenic pollution of the lake (Samakova, 2002).

Regular studies of algal communities in the Balkhash Lake have been carried out since 1971 (Abrosov, 1973; Kudekov, 2002; Ponomareva et al., 2005; Krupa et al., 2013, 2014a, 2014b). There is information on species composition, average values of quantitative parameters, as well as the interannual dynamics of the phytoplankton biomass in the previously published references.

The spatial distribution of phytoplankton is of particular interest besides the long-term variability. In large water bodies such as Balkhash Lake, it depends on many external factors. The correlation analysis does not reveal the connection or, alternatively, shows inconsiderable links between biotic and environmental parameters with their wide amplitude and multidirectional influence on aquatic organisms.

One of the informative methods of analysis is data mapping and the 3D Surface Plots construction. Both of these methods allow us to describe the nonlinear nature of variability of biotic parameters within the gradient of controlling factors along identifying coordinates of revealed concentration of aquatic organisms. Coherent changes in biota as an adaptive response to environmental conditions (Barinova and Nevo, 2012) also necessitates the analysis of internal links between the structural variables of communities. In particular, one of the debatable issues concerns the variability of size parameters and diversity of aquatic communities that expressed by the Shannon index within the gradient of external factors (Andronikova, 1996; Protasov and Pavlyuk, 2004; Penning et al., 2008). In this regard, the purpose of this work is to analyze spatial distribution of phytoplankton across the Balkhash Lake surface and to reveal the relationships between structural parameters of communities and environmental variables based on statistical mapping and 3D Surface Plots.

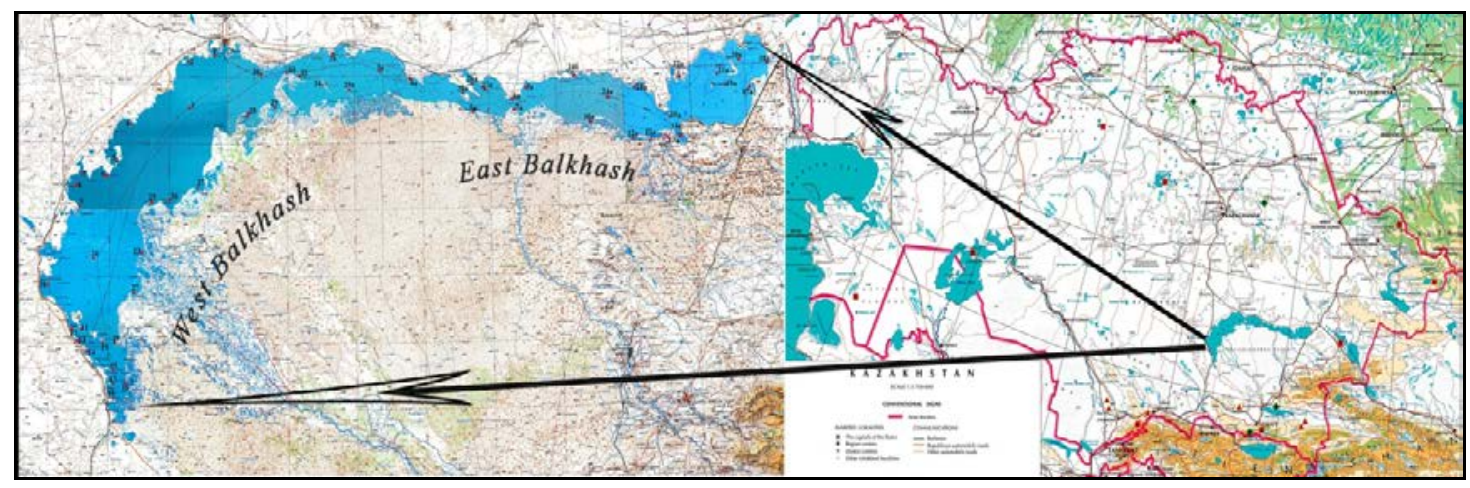

Figure 1: Map sampling stations at Balkhash Lake. 


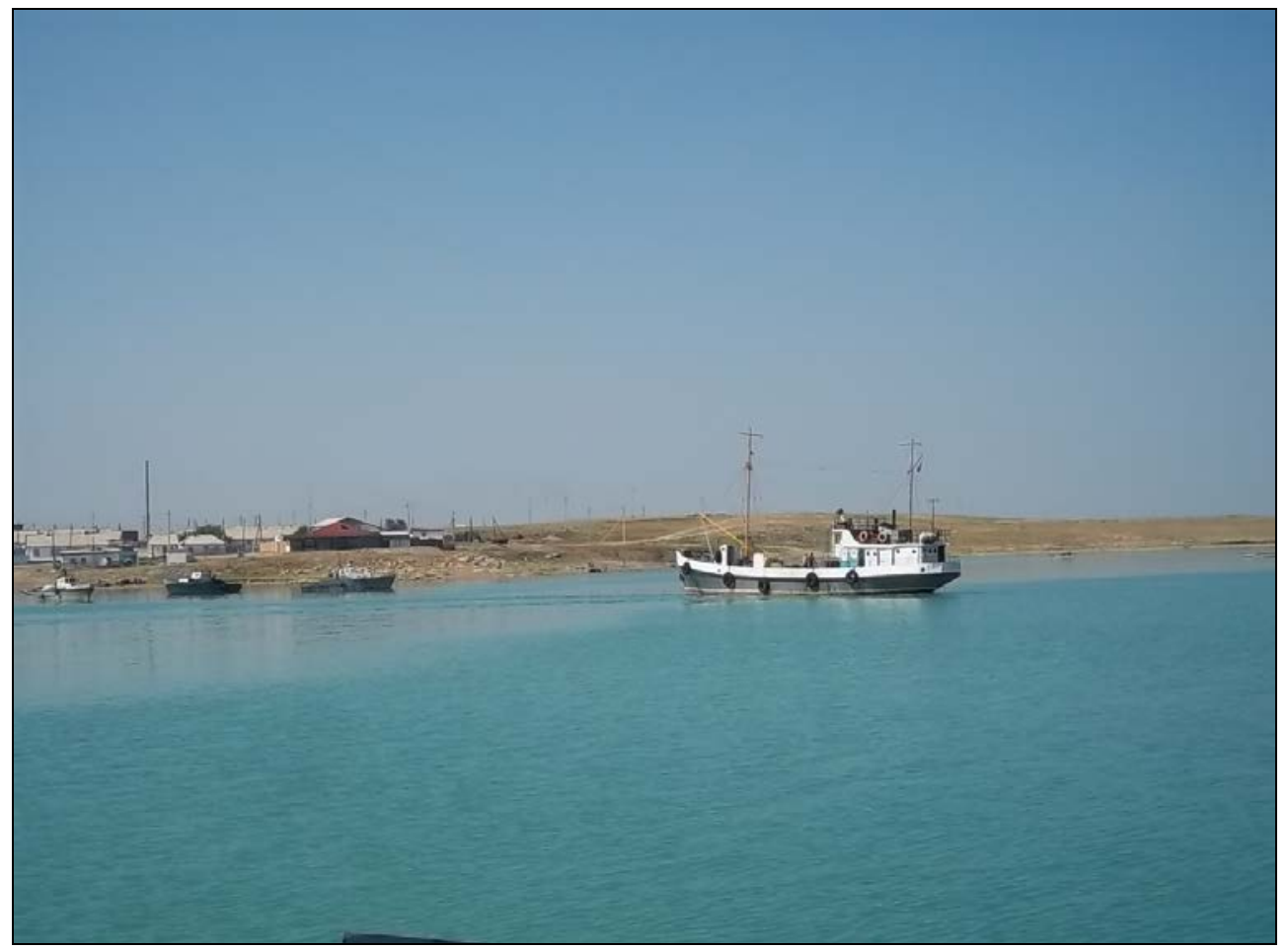

Figure 2: Balkhash Lake.

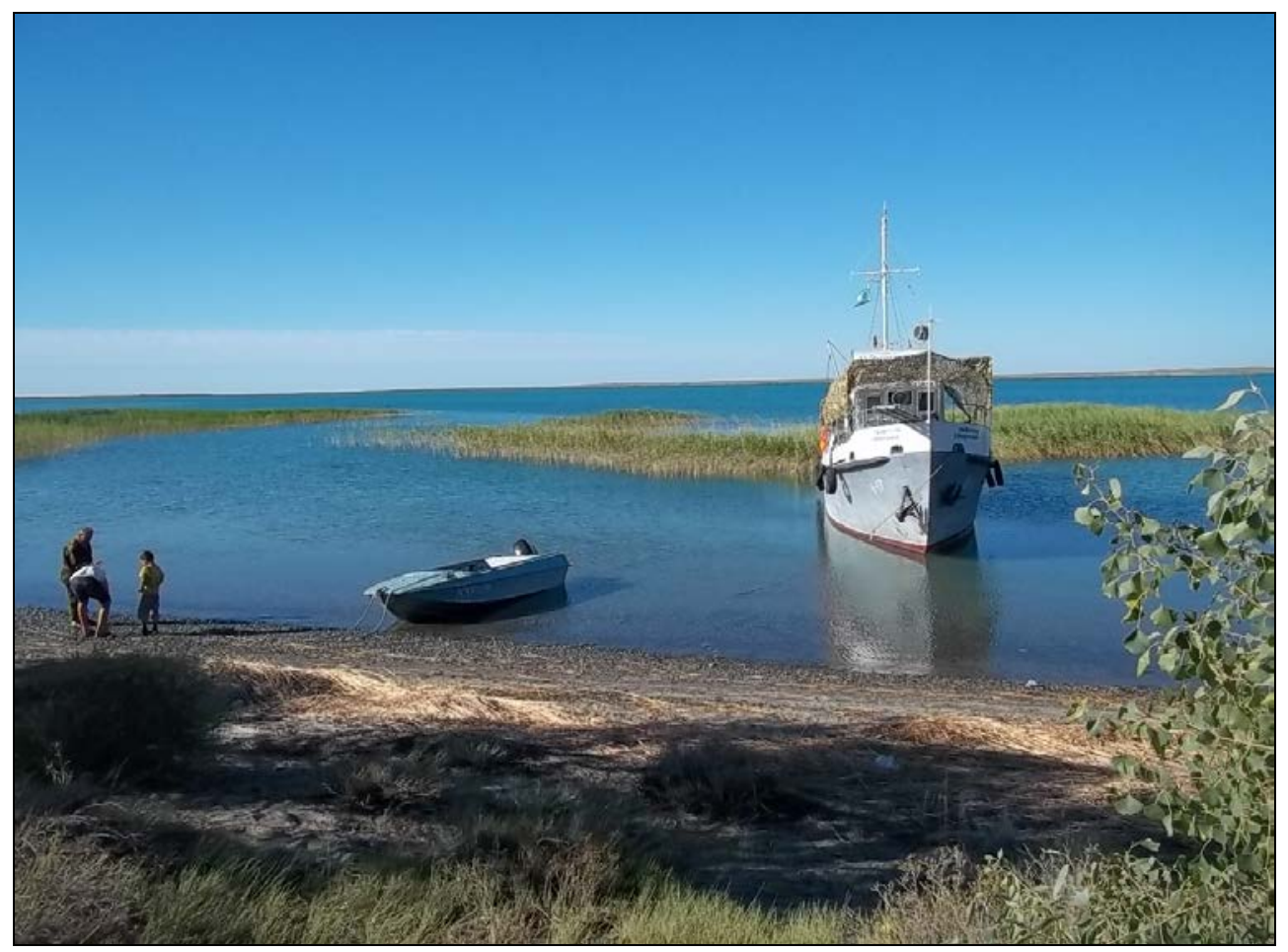

Figure 3: Balkhash Lake. 


\section{MATERIAL AND METHODS}

The phytoplankton research, Total Dissolved Solids (TDS), ionic water composition, content of biogenic elements and heavy metals in the water was carried out by means of a grid of 58 stations (Fig. 1) in June-July 2004. The temperature and pH values of the surface water layers were taken in the field environment. Water transparency was measured with Secchi disk. Coordinate referencing of the stations was done by Garmin eTrex GPS-navigator. The samples for heavy metals were fixed in the site by adding nitric acid; samples for biogenes were fixed with chloroform. All collected samples were transported to the lab in an icebox.

Chemical water variables were identified with help of methods in handbooks (Semenova, 1977; Fomin, 1995) in three - four repetitions. The standard error for major ions was $0.5-5.0 \%$, depending on the element. Inductively coupled plasma Mass spectrometer Agilent 7500 A manufactured by Agilent Technologies, USA (National Standard RK ISO 17294-2-2006) was used for the heavy metal analysis, with Abundance Sensitivity for Low Mass $<5 \times 10-7$, and High Mass $<1 \times 10-7$.

The phytoplankton samples were calculated with sediment gravimetric method (Kiselev, 1956). Species were identified with help of handbooks for relevant divisions (Zabelina et al., 1951; Gollerbach et al., 1953; Popova, 1955; Palamar-Mordvintseva, 1982; Moshkova and Gollerbach, 1986). Shannon index was calculated in Primer 5 program as the logarithm with base 2 for total number of individuals (Shannon Ab, bit/individual) and for biomass (Shannon Bi, bit/mg) (Magurran, 1998). The arithmetic difference between the two versions of the index ( $\Delta$-Shannon) was calculated. The $\Delta$-Shannon was represented by us in first for the plankton communities of the Kolsay mountain lakes (Krupa and Barinova, 2016). Domination Curves were calculated in Primer 5 program. W-statistic of Clarke was calculated automatically (Clarke, 1990). Its value indicates the position of the biomass curve relative to the abundance curve. A positive $\mathrm{W}$ value indicates that the biomass curve is higher than abundance curve, and vice versa. The average algal cell mass was calculated as ratio between the total biomass and the total abundance in phytoplankton sample.

The innovative approaches was 3D Surface Plots' construction and statistically generated wafer maps using the Statistica 12.0 program for analysis of biological and environmental variables' relationship.

\section{RESULTS}

\section{Environmental variables.}

The Western Balkhash depth was about $4.3 \mathrm{~m}$ in average, transparency about $0.5 \mathrm{~m}$, water temperature up to $23.5^{\circ} \mathrm{C}, \mathrm{pH}$ values about 8.52 , overgrowth by soft macrophytes was $28.3 \%$, by hard macrophytes about $18.0 \%$ during the study period. The Eastern Balkhash was deeper with 6.86 meters in average, water transparency up to $1.7 \mathrm{~m}$, temperature about $24.8^{\circ} \mathrm{C}$, and $\mathrm{pH}$ value about 8.74 . Soft and hard macrophytes occupied on average $22.0 \%$ and $22.14 \%$ of the water area of eastern part of the lake, respectively.

TDS of water in the Eastern Balkhash was statistically significantly higher than in the western part (Tab. 1). Sulphates and sodium prevailed in the ionic composition of water. Higher concentrations of nitrates, nitrites, iron, zinc, and copper were found in the Western Balkhash. Phosphates, cadmium, lead, nickel, and cobalt were present in large quantities in the Eastern Balkhash. The ammonium ions content did not differ in the both parts of the lake. 
Table 1: The Total Dissolved Solids (TDS), nutrient content and toxicants ( $\mathrm{mg} \mathrm{dm}^{-3}$ ) in the Balkhash Lake, with standard deviation, summer 2004.

\begin{tabular}{|l|c|c|c|}
\hline Variable & $\begin{array}{c}\text { Whole } \\
\text { Balkhash }\end{array}$ & $\begin{array}{c}\text { Western } \\
\text { Balkhash }\end{array}$ & $\begin{array}{c}\text { Eastern } \\
\text { Balkhash }\end{array}$ \\
\hline $\mathrm{TDS}$ & $2,286.0 \pm 236.0$ & $1,080.3 \pm 83.4$ & $3,436.8 \pm 286.7$ \\
\hline $\mathrm{NH}_{4}$ & $0.102 \pm 0.017$ & $0.103 \pm 0.013$ & $0.102 \pm 0.033$ \\
\hline $\mathrm{NO}_{3}$ & $0.945 \pm 0.244$ & $1.379 \pm 0.410$ & $0.492 \pm 0.226$ \\
\hline $\mathrm{NO}_{2}$ & $0.042 \pm 0.011$ & $0.060 \pm 0.013$ & $0.024 \pm 0.016$ \\
\hline $\mathrm{P}-\mathrm{PO}_{4}$ & $0.017 \pm 0.004$ & $0.011 \pm 0.003$ & $0.023 \pm 0.007$ \\
\hline $\mathrm{Zn}$ & $0.028 \pm 0.009$ & $0.039 \pm 0.018$ & $0.017 \pm 0.002$ \\
\hline $\mathrm{Cu}$ & $0.018 \pm 0.003$ & $0.022 \pm 0.005$ & $0.013 \pm 0.002$ \\
\hline $\mathrm{Cd}$ & $0.0036 \pm 0.0002$ & $0.0028 \pm 0.0002$ & $0.0044 \pm 0.0002$ \\
\hline $\mathrm{Pb}$ & $0.034 \pm 0.003$ & $0.021 \pm 0.002$ & $0.047 \pm 0.004$ \\
\hline $\mathrm{Ni}$ & $0.039 \pm 0.001$ & $0.037 \pm 0.002$ & $0.042 \pm 0.002$ \\
\hline $\mathrm{Co}$ & $0.013 \pm 0.001$ & $0.010 \pm 0.0005$ & $0.017 \pm 0.001$ \\
\hline
\end{tabular}

\section{Phytoplankton species richness}

Phytoplankton was represented by 91 species, 29 of which were green algae, 26 diatoms, 21 blue-greens, four charophytic, four euglenophytic species, three dinophytic, and one chrysophytic species. Planktonic algae in the Western Balkhash (Fig. 4a) was represented by 74 species mostly Chlorophyta, which was higher than that in the Eastern Balkhash (69), where the basis of species richness was formed by Bacillariophyta. The most frequently encountered species in the Western Balkhash were dinophyte Peridinium sp., diatom Cyclotella meneghiniana Kützing, and euglenophyte Trachelomonas sp. In the Eastern Balkhash, in addition to the last two species, diatom Navicula sp., green Franceia sp., bluegreens Snowella lacustris (Chodat) Komárek and Hindák, Gomphosphaeria aponina Kützing and Gloeocapsa sp. were widespread. The algal communities were represented usually by no more than 7-15 species. Local outbreaks of species richness of phytoplankton were recorded in the southeastern and southern shores of the lake (Fig. 4b).
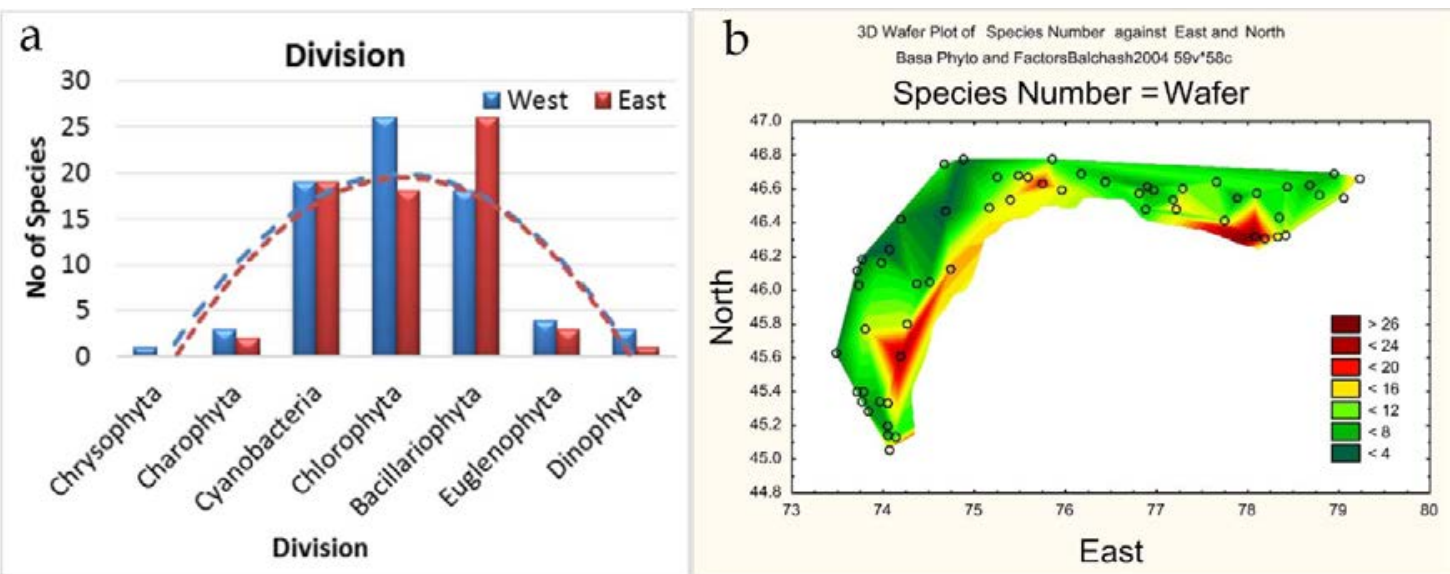

Figure 4: Distribution of species richness of phytoplankton over the taxonomic divisions in the eastern and western parts (a), and across the entire water area (b) of the Balkhash Lake, summer 2004. 


\section{Phytoplankton abundance and biomass}

The quantitative parameters of phytoplankton were at a lower level in the western freshened part of the water area than in the eastern part (Tab. 2). Cyanobacteria was dominant on average across the lake in both abundance and biomass. Bacillariophyta was subdominant. Euglenophyta was essential in forming total biomass of algae. The proportion of Bacillariophyta in forming the quantitative parameters of the communities increased in the direction from west to east for abundance from 10.1 to $16.5 \%$, and for biomass from 17.6 to 29.1\%. The role of Cyanobacteria in community, on the contrary, declined for abundance from 73.9 to $66.0 \%$, and for biomass from 47.6 to $44.6 \%$. There was more pronounced decrease in the eastern direction for Euglenophyta regarding abundance a drop from 7.6 to 6.6\%, and for total biomass from 24.9 to $15.2 \%$.

Table 2: Quantitative parameters of phytoplankton of the Balkhash Lake, summer 2004.

\begin{tabular}{|c|c|c|c|c|c|c|c|c|}
\hline $\begin{array}{l}\text { Part of } \\
\text { the lake }\end{array}$ & $\begin{array}{l}\text { Bacillar } \\
\text { iophyta }\end{array}$ & $\begin{array}{l}\text { Charo } \\
\text { phyta }\end{array}$ & $\begin{array}{l}\text { Chloro } \\
\text { phyta }\end{array}$ & $\begin{array}{l}\text { Chryso } \\
\text { phyta }\end{array}$ & $\begin{array}{l}\text { Cyano } \\
\text { bacteria }\end{array}$ & $\begin{array}{l}\text { Dino } \\
\text { phyta }\end{array}$ & $\begin{array}{l}\text { Eugle } \\
\text { nophyta }\end{array}$ & Total \\
\hline \multicolumn{9}{|c|}{ Abundance, mln. ind. $\mathrm{m}^{-3}$} \\
\hline $\begin{array}{l}\text { Western } \\
\text { Balkhash }\end{array}$ & 87.0 & 6.0 & 52.3 & 2.0 & 658.4 & 16.3 & 67.4 & 889.5 \\
\hline $\begin{array}{l}\text { Eastern } \\
\text { Balkhash }\end{array}$ & 186.5 & 5.7 & 92.3 & 0.0 & 776.1 & 12.6 & 46.3 & $1,119.4$ \\
\hline average & 135.8 & 5.6 & 72.0 & 1.0 & 716.2 & 14.5 & 57.1 & $1,002.4$ \\
\hline \multicolumn{9}{|c|}{ Biomass, $\mathrm{g} \mathrm{m}^{-3}$} \\
\hline $\begin{array}{l}\text { Western } \\
\text { Balkhash }\end{array}$ & 0.150 & 0.015 & 0.039 & 0.004 & 0.353 & 0.020 & 0.211 & 0.796 \\
\hline $\begin{array}{l}\text { Eastern } \\
\text { Balkhash }\end{array}$ & 0.243 & 0.008 & 0.041 & 0.000 & 0.404 & 0.023 & 0.093 & 0.812 \\
\hline average & 0.211 & 0.011 & 0.043 & 0.002 & 0.394 & 0.022 & 0.167 & 0.853 \\
\hline
\end{tabular}

The largest concentrations of plankton algae were confined to the mouths of the flowing rivers (Figs. 5 and 6). The local increases in abundance or biomass of dinophyte, euglenophyte, and blue-green algae were recorded in some parts of the water area. Chrysophyte algae were found only in the western freshwater part of the lake.

\section{Phytoplankton community structure}

The diversity of phytoplankton communities was at moderate and elevated levels according to mean values of Shannon Ab and Shannon Bi (Tab. 3). The minimal values of the Shannon index were revealed for the phytoplankton of the western part of the lake, as well as of the deep-water areas of the Eastern Balkhash (Figs. 7a, b). The distribution of algal species over biomass was less even than over abundance, which was reflected in the negative values of $\Delta$-Shannon (Tab. 3). The negative values of W-Clarke indicated that the abundance curve was above the biomass curve, and therefore small-sized species dominated the community. The values of $\Delta$-Shannon and $\mathrm{W}$-statistics of Clarke across the lake area were changing synchronously (Figs. 7c, d).

An average volume of an algal cell varied across the water area by orders of magnitude with its maximal value being in the Western Balkhash (Fig. 7e). The average number of species in a sample and the Shannon Ab and Shannon Bi index values were higher and the average mass of an algal cell was lower in the Eastern Balkhash compared to the western part (Tab. 3). The phytoplankton of the western part of the water area was characterized by a more pronounced shift of $\Delta$-Shannon and W-Clarke towards the negative range in comparison with the Eastern Balkhash. 

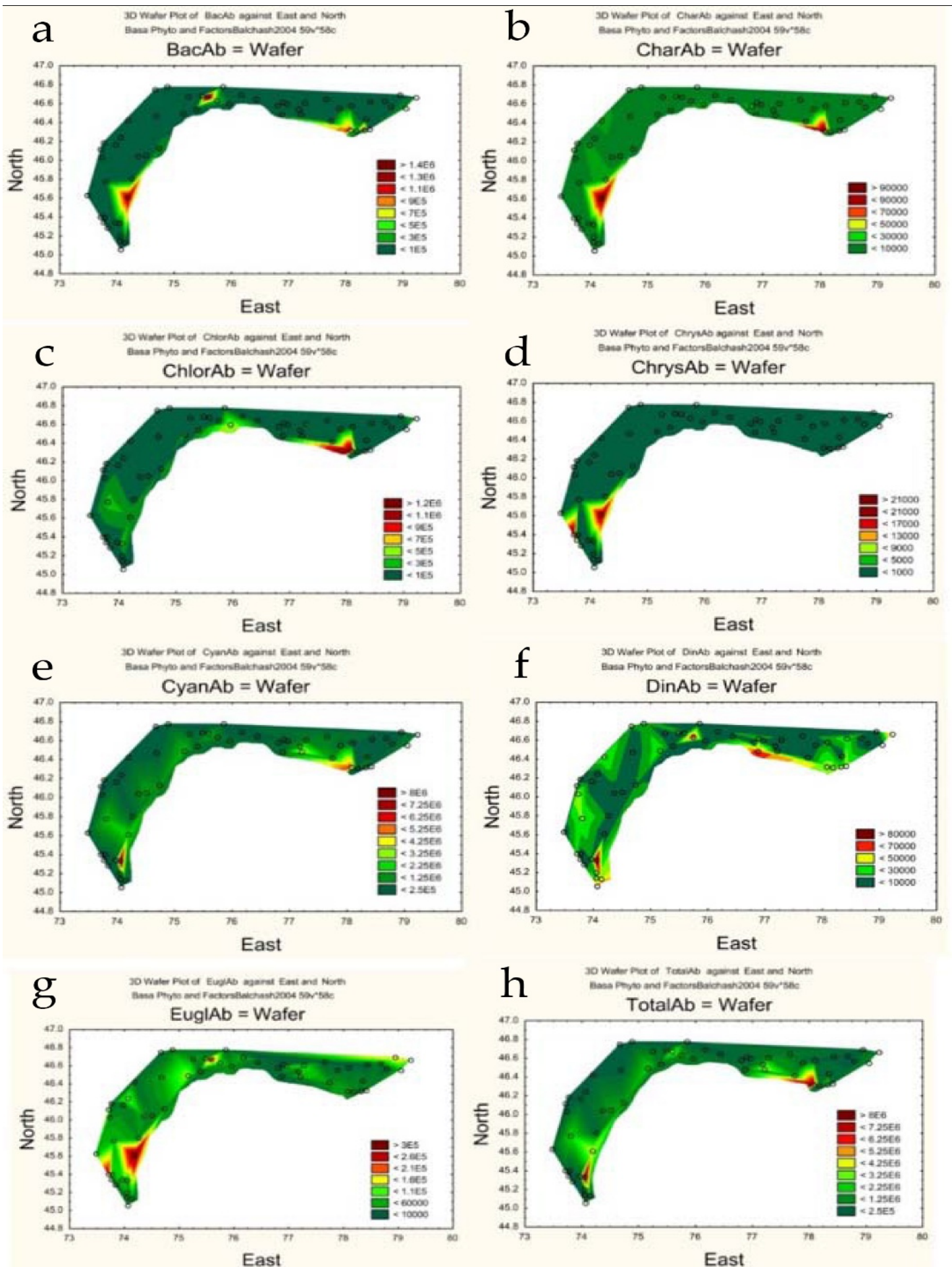

Figure 5: The spatial distribution of the Divisional phytoplankton abundance across the water area of the Balkhash Lake, summer 2004. 

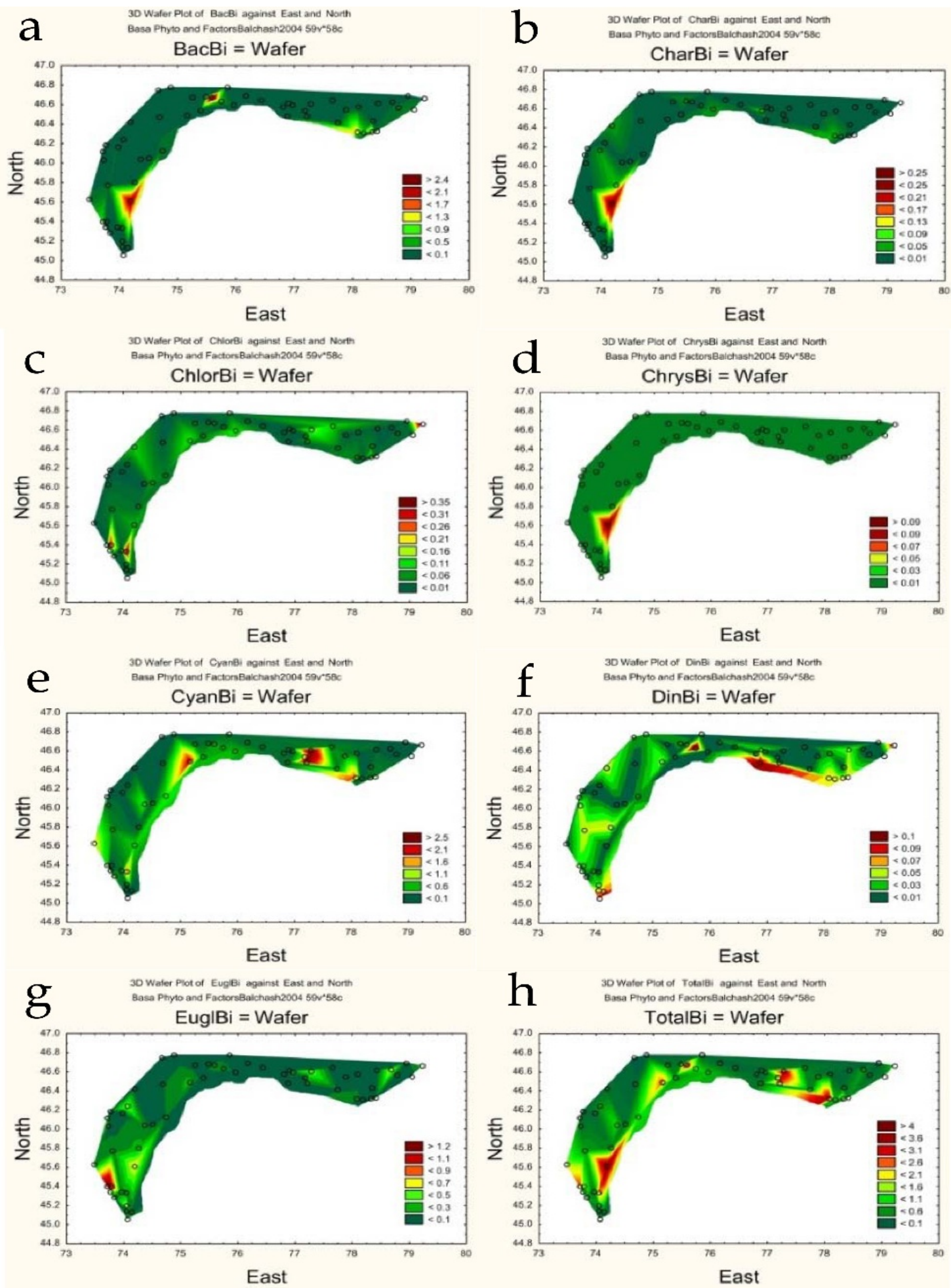

Figure 6: Spatial distribution of the Divisional phytoplankton biomass across the water area of the Balkhash Lake, summer 2004. 
Table 3: Structural variables of phytoplankton of the Balkhash Lake, summer 2004.

\begin{tabular}{|l|l|l|l|l|l|l|}
\hline $\begin{array}{c}\text { Part } \\
\text { of the } \\
\text { lake }\end{array}$ & \multicolumn{1}{|c|}{$\begin{array}{c}\text { Species } \\
\text { number }\end{array}$} & $\begin{array}{c}\text { Average } \\
\text { mass, } \\
\mathrm{mg} \times 10^{-6}\end{array}$ & $\begin{array}{c}\text { Shannon } \\
\mathrm{AB}\end{array}$ & $\begin{array}{c}\text { Shannon } \\
\mathrm{BI}\end{array}$ & $\Delta$-Shannon & W-Clarke \\
\hline $\begin{array}{l}\text { Western } \\
\text { Balkhash }\end{array}$ & 9.1 & 1.894 & 2.27 & 1.91 & -0.358 & -0.167 \\
\hline $\begin{array}{l}\text { Eastern } \\
\text { Balkhash }\end{array}$ & 11.7 & 1.042 & 2.50 & 2.35 & -0.150 & -0.061 \\
\hline average & 10.6 & 1.613 & 2.40 & 2.13 & -0.270 & -0.120 \\
\hline
\end{tabular}
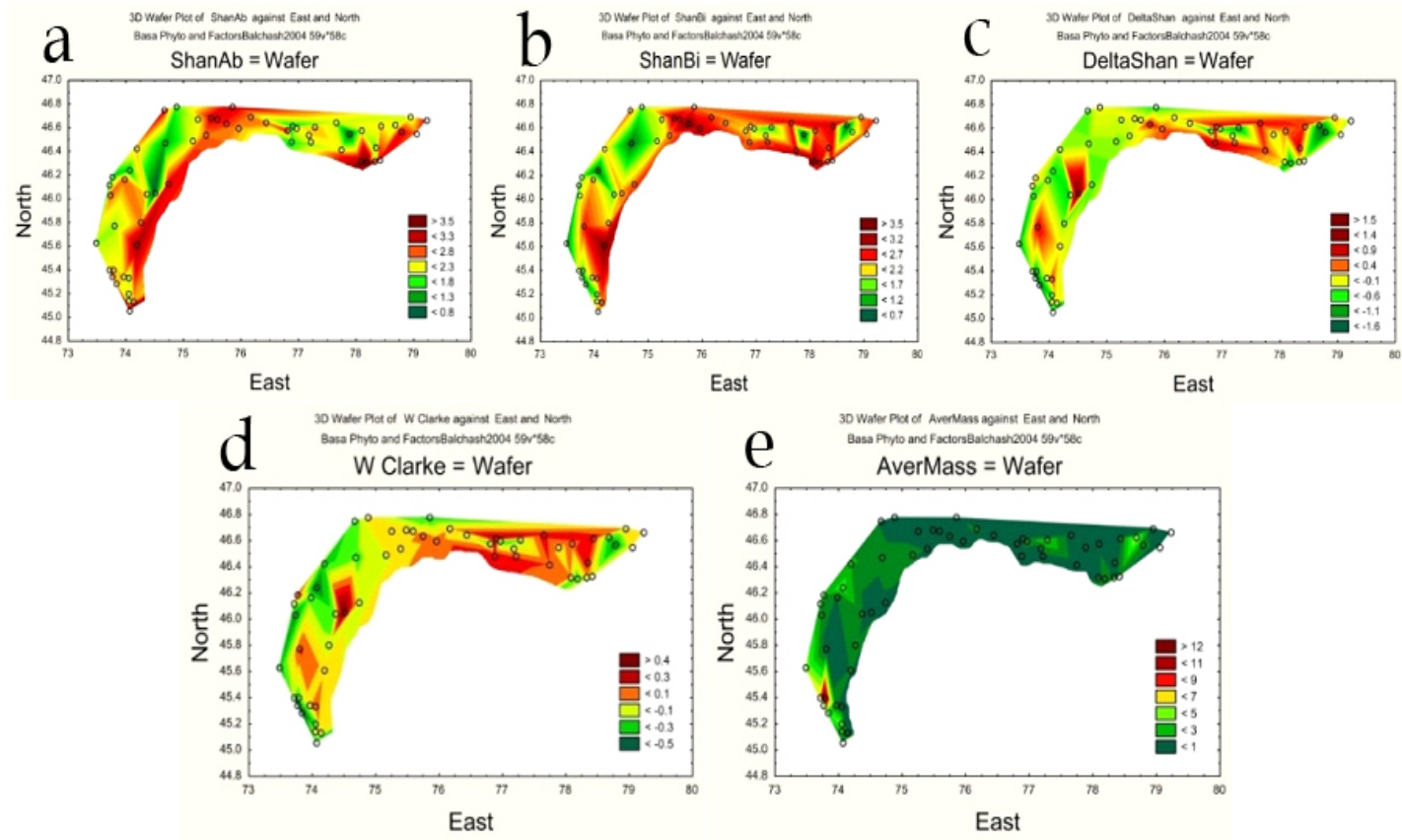

Figure 7: Spatial distribution of structural variables of phytoplankton communities across the water area of the Balkhash Lake, summer 2004.

Correlation analysis (Tab. 4) revealed decreasing of algal cell mass when the phytoplankton total abundance, total biomass, species richness, and the values of Shannon Bi and W-Clarke indices increase. A statistically significant but weak relationship between the values of Shannon $\mathrm{Bi}$ and Shannon $\mathrm{Ab}$ indicated that these variables were under influence of diverse factors. The Shannon Bi index that directly connected to species richness was higher in the small-sized communities, whereas the Shannon Ab index was positively correlated with number of species only. Both indices, $\mathrm{W}$-Clarke and $\Delta$-Shannon, having very close positive relationship and showed negative correlation with average cell mass and positive - with Shannon Bi. 
Table 4: The coefficients of Spearman Rank Order Correlations between phytoplankton structure in Balkhash Lake, summer 2004, p $<0.05$.

\begin{tabular}{|c|c|c|c|}
\hline $\begin{array}{c}\text { Paired } \\
\text { variables }\end{array}$ & $\begin{array}{c}\text { Spearmen } \\
\text { rank } \\
\text { order } \\
\text { correlations }\end{array}$ & $\begin{array}{c}\text { Paired } \\
\text { variables }\end{array}$ & $\begin{array}{l}\text { Spearmen } \\
\text { rank } \\
\text { order } \\
\text { correlations }\end{array}$ \\
\hline $\begin{array}{l}\text { Total Ab - } \\
\Delta \text {-Shannon }\end{array}$ & 0.414 & $\begin{array}{l}\text { Shannon Ab- } \\
\Delta \text {-Shannon }\end{array}$ & -0.373 \\
\hline $\begin{array}{l}\text { Total Ab- } \\
\text { Average Mass }\end{array}$ & -0.532 & $\begin{array}{l}\text { Shannon Ab - } \\
\text { W Clarke }\end{array}$ & -0.334 \\
\hline $\begin{array}{l}\text { Total Ab - } \\
\text { Shannon Bi }\end{array}$ & 0.554 & $\begin{array}{l}\text { Shannon Bi- } \\
\text { Species Number }\end{array}$ & 0.735 \\
\hline $\begin{array}{l}\text { Total Ab - } \\
\text { Species } \\
\text { Number }\end{array}$ & 0.686 & $\begin{array}{l}\text { Shannon } \mathrm{Bi}- \\
\text { Average Mass }\end{array}$ & -0.611 \\
\hline $\begin{array}{l}\text { Total Ab - W } \\
\text { Clarke }\end{array}$ & 0.450 & $\begin{array}{l}\text { W Clarke - } \\
\Delta \text {-Shannon }\end{array}$ & 0.956 \\
\hline $\begin{array}{l}\text { Total Bi - } \\
\text { Average Mass }\end{array}$ & - & $\begin{array}{l}\text { W Clarke - } \\
\text { Average Mass }\end{array}$ & -0.701 \\
\hline $\begin{array}{l}\text { Total Bi - } \\
\text { Species } \\
\text { Number }\end{array}$ & 0.448 & $\begin{array}{l}\text { W Clarke - } \\
\text { Shannon Bi }\end{array}$ & 0.623 \\
\hline $\begin{array}{l}\text { Total Bi - } \\
\text { Total Ab }\end{array}$ & 0.633 & $\begin{array}{l}\Delta \text {-Shannon - } \\
\text { Average Mass }\end{array}$ & -0.705 \\
\hline $\begin{array}{l}\text { Shannon Ab - } \\
\text { Shannon Bi }\end{array}$ & 0.426 & $\begin{array}{l}\Delta \text {-Shannon - } \\
\text { Shannon Bi } \\
\end{array}$ & 0.636 \\
\hline $\begin{array}{l}\text { Shannon Ab - } \\
\text { Species } \\
\text { Number }\end{array}$ & 0.650 & $\begin{array}{l}\text { Average Mass - } \\
\text { Species Number }\end{array}$ & -0.369 \\
\hline
\end{tabular}

Statistically generated 3-D Surface Plots demonstrated the complex nature of the relationship between various structural variables of phytoplankton. Small-sized algal communities that consisted of the large number of species formed the largest total abundance; abundance of few-species communities was at a lower level and stayed approximately the same within the entire gradient of the cell size parameter (Fig. 8a). Maximal biomass was formed by large-sized communities represented by the largest number of species (Fig. 8b).

The Shannon Ab index values increased almost linearly in multi-species large-size algal communities (Fig. 8c). In contrast, the Shannon Bi values were positively affected by a decrease in the average mass of an algal cell in the multi-species communities (Fig. 8d). The second peak of phytoplankton diversity, which was significantly smaller in absolute values, was revealed in the few-species communities within the entire gradient of the cell size parameter. An almost linear positive relationship between the values of W-Clarke and $\Delta$-Shannon was noted within the gradient of the cell size parameter, with the largest shift of $\mathrm{W}$-Clarke to the region of positive values in small-celled communities. Like $\Delta$-Shannon, W-Clarke values demonstrated close, almost linear connection with both versions of Shannon variety index (Fig. 8f). The values of $\mathrm{W}$-Clarke and $\Delta$-Shannon, close in their positive relationship, were maximal in communities represented by small-celled species within an entire gradient of species richness (Figs. 8g, h). The second, less pronounced W-Clarke extremum was recorded in large-celled communities with medium species richness. 
3D Surface Plot of Totalab against Species Number and AverMass TotalAb = Distance Weighted Least Squares

a

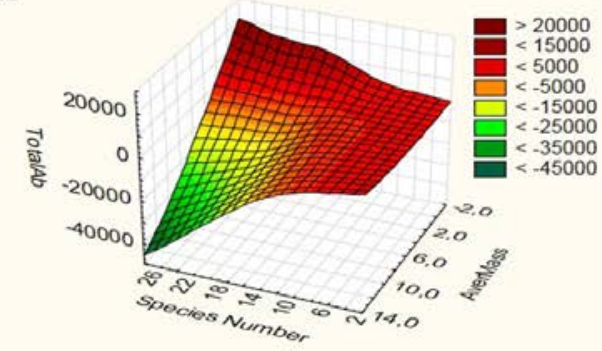

3D Surface Plot of ShanAb against Species Number and AverMass Basa Phyto and FactorsBalchash2004_W_River 68v*56c Shan $\mathrm{Ab}=$ Distance Weighted Least Squares

C

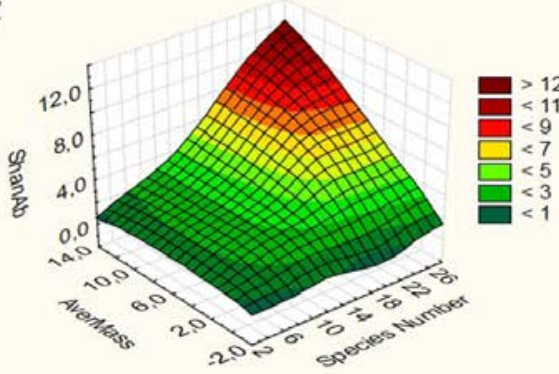

3D Surface Plot of W Clarke against DeltaShan and AverMass Basa Phyto and FactorsBalchash2004 W River $68 v^{*} 56 c$ $\mathrm{W}$ Clarke $=$ Distance Weighted Least Squares

e

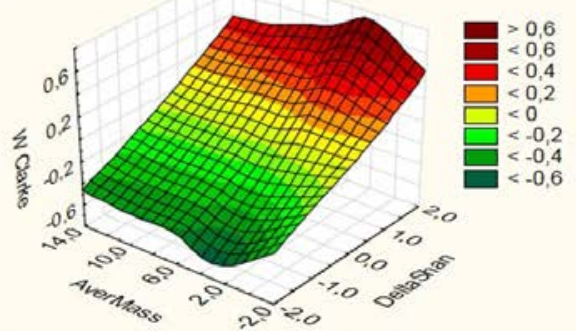
Basa Phyto and FactorsBalchash2004_W_River 68v'56c
DeltaShan = Distance Weighted Least Squares $\mathrm{g}$

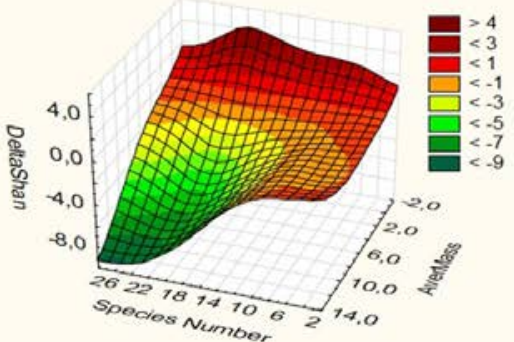

3D Surface Plot of TotalBi against Species Number and AverMass
Basa Phyto and FactorsBalchash2004 W River $68 \mathrm{v}^{\circ} 56 \mathrm{c}$ TotalBi $=$ Distance Weighted Least Squares b

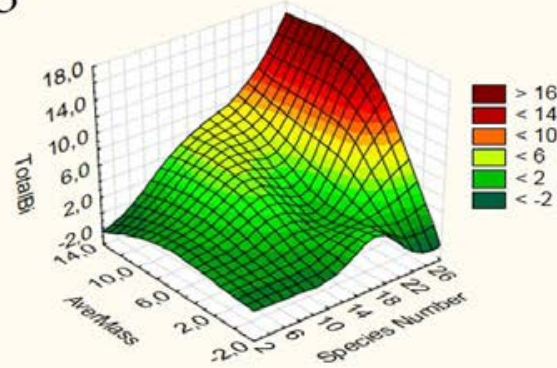

30 Surface Plot of ShanBi against Species Number and AverMass Basa Phyto and FactoreBalchash2004 W River 68v"56c Shan $\mathrm{Bi}=$ Distance Weighted Least Squares d

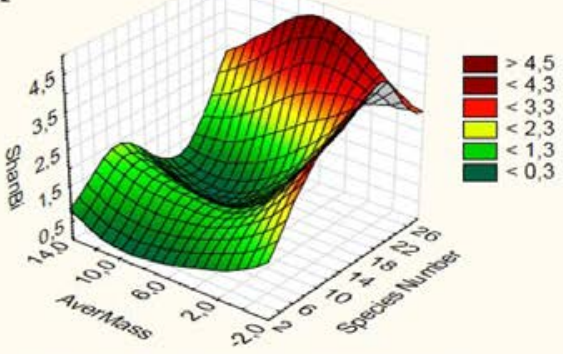

3D Surface Plot of W Clarke against ShanBi and ShanAb $\mathrm{W}$ Clarke $=$ Distance Weighted Least Squares

f

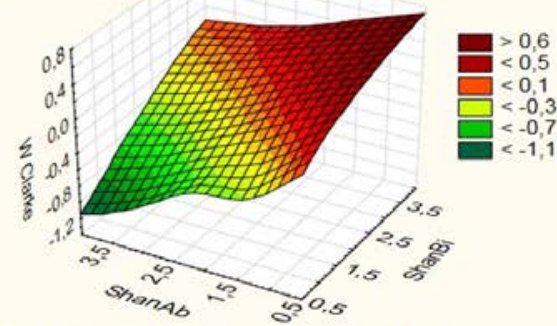

3D Surface Plot of $W$ Clarke against Species Number and AverMass Basa Phyto and FactorsBalchash2004_W_River $68 v^{\circ} 56 \mathrm{c}$ $\mathrm{W}$ Clarke $=$ Distance Weighted Least Square h

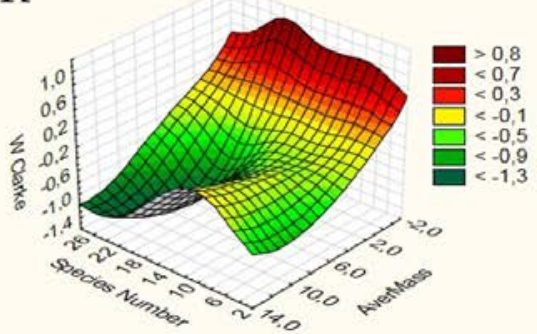

Figure 8: 3-D Surface Plots of structural variables of phytoplankton in the Balkhash Lake, summer 2004. 


\section{DISCUSSION}

Phytoplankton of the Balkhash Lake was represented by 91 species in summer communities of 2004 with the greatest variety of green, diatom and blue-green algae. The average abundance of plankton algae across the lake was 1,002.4 mln ind. $\mathrm{m}^{-3}$ and average biomass was $0.853 \mathrm{~g} \mathrm{~m}^{-3}$. Regarding the biomass of phytoplankton, the Balkhash Lake is more productive than some other large water bodies in the region including the Shardara Reservoir (Barinova and Krupa, 2017a, b) (Tab. 5).

Table 5: Comparative characteristics of structural variables of phytoplankton in some water bodies of Kazakhstan.

\begin{tabular}{|l|l|l|l|l|l|l|l|}
\hline $\begin{array}{l}\text { Water } \\
\text { body }\end{array}$ & $\begin{array}{l}\text { Abundance, } \\
\text { mln. ind. } \\
\mathrm{m}^{-3}\end{array}$ & $\begin{array}{l}\text { Biomass, } \\
\mathrm{g} \mathrm{m}^{-3}\end{array}$ & $\begin{array}{l}\text { Average } \\
\text { mass, } \\
\mathrm{mg} 10^{-6}\end{array}$ & $\begin{array}{l}\text { Shan } \\
\text { non } \\
\mathrm{Ab}\end{array}$ & $\begin{array}{l}\text { Shan } \\
\text { non } \\
\mathrm{BI}\end{array}$ & $\begin{array}{l}\Delta- \\
\text { Shannon }\end{array}$ & $\begin{array}{l}\text { W- } \\
\text { Clarke }\end{array}$ \\
\hline $\begin{array}{l}\text { Western } \\
\text { Balkhash }\end{array}$ & 889.5 & 0.796 & 1.894 & 2.27 & 1.91 & -0.358 & -0.167 \\
\hline $\begin{array}{l}\text { Eastern } \\
\text { Balkhash }\end{array}$ & $1,119.4$ & 0.812 & 1.042 & 2.50 & 2.35 & -0.150 & -0.061 \\
\hline $\begin{array}{l}{ }^{*} \text { Lower } \\
\text { Kolsay }\end{array}$ & 510.2 & 0.226 & 0.442 & 2.16 & 2.61 & 0.450 & -0.077 \\
\hline $\begin{array}{l}* \text { Middle } \\
\text { Kolsay }\end{array}$ & 75.0 & 0.451 & 6.009 & 2.38 & 1.94 & -0.440 & 0.127 \\
\hline $\begin{array}{l}\text { *Upper } \\
\text { Kolsay }\end{array}$ & 110.1 & 0.477 & 4.335 & 2.67 & 2.25 & -0.420 & 0.136 \\
\hline $\begin{array}{l}* \text { Sary- } \\
\text { Bulak }\end{array}$ & 11.7 & 0.078 & 6.692 & 2.24 & 1.14 & -1.100 & 0.610 \\
\hline **Shardara & 544.0 & 0.626 & 1.660 & 3.80 & 3.41 & -0.380 & -0.095 \\
\hline
\end{tabular}

Quantitative parameters of phytoplankton show lower values in the freshwater Western Balkhash compared to the eastern saline part of the water area (Tab. 2) due to the controlling impact of the bivalve mollusk Monodacna colorata (Eichwald, 1829; Krupa et al., 2013) that feeds on protozoans, organic substances, bacteria and planktonic algae (Alimov, 1981). Sharp decrease in the total biomass of algae in the western part of the water area has been observed according to our data (Krupa et al., 2013) since 1996 when the biomass of macrozoobenthos, due to the mollusk, reached unprecedented values for the Balkhash Lake up to 14-50 $\mathrm{g} \mathrm{m}^{-2}$. Reorganization of the benthic community structure, in turn, has been caused by a reduction of the commercial stock of benthic fish, primarily carp, whose population due to its disruption is mainly represented by specimens of younger ages (Kenzhebekov et al., 2011).

Mapping of measured data revealed concentration of plankton algae in the areas near mouths of inflowing rivers as well as in the shallows of the Eastern Balkhash. The relationship between the abundance of planktonic algae and river runoff is natural since most of the nutrient elements enter the lake with the waters of rivers and therefore the near-mouth areas are freshened. We earlier (Krupa and Barinova, 2016) noted the confinement of phytoplankton to the shallow-water areas that are influenced by the river runoff.

Very important is the size structure parameters among characteristics of communities, which in integral form reflect the ratio of the species in different ecological groups. Comparative analysis showed (Tab. 5) that the phytoplankton of the Balkhash Lake is represented by smaller species than in the algal communities of the mountain lakes Middle 
Kolsay, Upper Kolsay, Sary-Bulak (Krupa and Barinova, 2016). We revealed similar values of the cell size parameter for algal communities of the Shardara Reservoir (Barinova and Krupa, 2017a, b). The smallest-size community was exhibited by phytoplankton of the mountain lake Lower Kolsay, which is associated with its eutrophication against the backdrop of a decrease of the water level (Krupa et al., 2016a, b).

Changes in size parameters that accompanied by other rearrangements in the structure of community were reflected in the values of W-Clarke and Shannon diversity index. The values of the former indicator were positive only for large-sized phytoplankton communities of the Kolsay Lakes (Tab. 5). The diversity of phytoplankton of the Balkhash Lake compared to other water bodies was moderate according to the values of the indices Shannon Ab and Shannon Bi.

The 3-D Surface Plots illustrated an internal relationship between diverse structural parameters of phytoplankton communities of the Balkhash Lake. The total abundance of planktonic algae that represented by a small number of species was at a low level within the entire gradient of size parameter. Higher abundance of algal communities that consist of a large number of small-cell species corresponded with a general principle of successive development of aquatic ecosystems (Odum, 1986). Large-size communities that were also represented by the largest number of species formed maximal biomass. The values of Shannon $\mathrm{Ab}$ index increased almost linearly in multi-specific large-size algal communities. In contrast, Shannon Bi values were positively affected by a decrease in the average mass of an algal cell in multi-specific communities. The second peak of phytoplankton diversity, which was smaller in absolute values, was revealed in the few-specific communities within the entire gradient of the cell size parameter. That is, the values of the diversity index of Shannon Ab and Shannon $\mathrm{Bi}$ depended on the species richness, but species in the small-sized communities were more evenly distributed according to their biomass. A negative relationship between Shannon Bi index and algal cell size parameters of plankton communities was noted earlier for other water bodies in the region (Krupa, 2012; Krupa and Barinova, 2016; Barinova and Krupa, 2017a, b).

The values of $\Delta$-Shannon and $\mathrm{W}$-Clarke were in close connection with each other as well as with Shannon $\mathrm{Bi}$ and Shannon Ab maximizing in communities represented by smallsized species. A strong statistically significant relationship between $\Delta$-Shannon and W-Clarke was found for the phytoplankton communities of diverse water bodies in Kazakhstan such as the Kolsay Lakes (Krupa and Barinova, 2016) and the Shardara Reservoir (Barinova and Krupa, 2017a, b).

The obtained results allow us to conclude that the introduced index $\Delta$-Shannon along with W-Clarke can both be illustrative of the community structure assessment. The average mass of an algal cell, $\Delta$-Shannon, and $\mathrm{W}$-Clarke values are closely related but described the structure of hydrocoenosis from different point of view. There is the need not only for further studies on the variability of structural parameters within the gradient of external factors, but also the analysis of relationships within the communities of hydrobionts. The statistical data mapping can serve as a valuable addition to correlation analysis methods that reveal only linear relationships between the variables. Statistically generated maps have some prognostic properties that together with the three-dimensional graphs allow us to describe the non-linear variability of the dependent variable within the gradient of controlling factors. 


\section{CONCLUSIONS}

In the summer of 2004, according to our research, phytoplankton of the Balkhash Lake was represented by 91 species, with the greatest variety of green, diatom and blue-green algae. Average abundance amounted to 1,002.4 mln. ind. $\mathrm{m}^{-3}$, and average biomass reached $0.853 \mathrm{~g}$ $\mathrm{m}^{-3}$. The lower quantitative parameters of phytoplankton were found in the Western Balkhash, which is due to the controlling influence of the bivalve Monodacna colorata. Analysis of spatial distribution with by means of statistical maps showed the development of phytoplankton intensified near mouths of the inflowing rivers as well as in the shallows of the Eastern Balkhash. Euglenophyta preferred and Chrysophyta developed in the western freshened part of the water area. The relationship between structural parameters within communities was revealed. The decrease in the average mass of an algal cell occurred against the backdrop of an increase in phytoplankton abundance, species richness, and the values of Shannon Bi and Shannon Ab indices. The Shannon Ab index value depended only on the number of species in the community, whereas Shannon Bi index had a positive relationship with the number of species and a negative relationship with the average cell mass. The maximal values of biomass were formed in large-cell multi-specific communities. The higher abundance of algal communities of small-celled species corresponded to the overall change in phytoplankton structure due to eutrophication. The synchronicity of spatial dynamics of the W-Clarke and $\Delta$-Shannon values evidenced the possibility of obtaining information on the dimensional structure of hydrocoenosis both calculated and graphical methods.

Data visualization by means of the statistically generated maps and 3D Surface Plots serve as a good addition to the other statistical analysis methods, as it allows capturing nonlinear relationships between variables, including links within biotic communities.

\section{ACKNOWLEDGEMENTS}

The work was carried out partly under the project no. 1846/ГФ4 Г.2015-Г2016 for Committee of Science, Ministry of Education and Science, Republic of Kazakhstan "Development of the methods for controlling the ecological state of water bodies in Kazakhstan", "Study of the modern hydroecological state of fishery water reservoirs and development of biological justifications for the purposefulness and priority of fishery reclamation for conservation and enhancement of the fishery potential of the reservoir” as well as partly supported by the Israeli Ministry of Absorption.

\section{REFERENCES}

1. Abrosov V. N., 1973 - Lake Balkhash, Leningrad, Russia, Science, 181. (in Russian)

2. Alimov A. F., 1981 - Functional ecology of bivalve mollusks, Proceedings of the Zoological Institute of the Academy of Sciences of the USSR, 96, Leningrad, Russia, Leningrad Branch, 248. (in Russian)

3. Andronikova I. N., 1996 - Structurally and functional organization of zooplankton of lake ecosystems of different trophic types, Saint Petersburg, Russia, Science, 189. (in Russian)

4. Barinova S. and Nevo E., 2012 - Algal diversity of the Akko Park wetlands in the Bahai Gardens (Haifa, Israel), Transylvanian review of Systematical and Ecological Research, 14, The Wetlands Diversity, 55-80.

5. Barinova S. and Krupa E., 2017a - Bioindication of Ecological State and Water Quality by Phytoplankton in the Shardara Reservoir, Kazakhstan, Environment and Ecology Research, 5, 73-92.

6. Barinova S. and Krupa E., 2017b - Critical environmental factors for photosynthetic organisms of the Shardara reservoir, Kazakhstan, Asian Journal of Microbiology, Biotechnology and Environmental Sciences, in press. 
7. Clarke K. R., 1990 - Comparison of dominance curves, Journal of Experimental Marine Biology and Ecology, 138, 143-157.

8. Fomin G. S., 1995 - Water. Control of chemical, bacterial and radiation safety according to international standards, Moscow, Russia, NGO “Alternative”, 618. (in Russian)

9. Gollerbach M. M., Kossinskaya E. K. and Polyansky V. I., 1953 - Key to freshwater algae of USSR, 2, Blue-green algae, Moscow, Russia, 654. (in Russian)

10. Kenzhebekov B. K., Asylbekova S. Z., Isbekov K. B. and Anurieva A. N., 2011 - Dependence of number of individual fish species in lake Balkhash on abiotic factors, Water resources and their rational use. Bulletin of the Agrarian Technical University, Fisheries, 2, 3-17. (in Russian)

11. Kiselev I. A., 1956 - Methods of study of plankton, in Life of freshwaters of the USSR, 4, Moscow, Leningrad, Russia, 183-265. (in Russian)

12. Krupa E. G., 2012 - Zooplankton of limnetic and running water ecosystems in Kazakhstan. Structure, forming patterns, Saarbrücken Palmarium Academic Publishing, 346. (in Russian)

13. Krupa E. G., Tsoi V. N., Lopareva T. Y., Ponomareva L. P., Anureva A. N., Sadyrbaeva N. N., Asylbekova S. J. and Isbekov K. B., 2013 - Long-term dynamics of aquatic organisms of the Balkhash Lake and its relationship with environmental factors, Bulletin of the Astrakhan State Technical University, 2, 85-96. (in Russian)

14. Krupa E., Slyvinskiy G. and Barinova S., 2014a - The effect of climatic factors on the long-term dynamics of aquatic ecosystem of the Balkhash Lake (Kazakhstan, Central Asia), Advanced Studies in Biology, 6, 3, 115-136.

15. Krupa E. G., Sadyrbaeva N. N., Ponomareva L. P., Anurieva A. N. and Assylbekova S. Z., 2014b - The long-term variability of phytoplankton, zooplankton and macrozoobenthos in the lake Balkhash, Bulletin of the Kazakh National University, 1/1, 40, 296-304. (in Russian)

16. Krupa E. G. and Barinova S. S., 2016a - Environmental Variables Regulating the Phytoplankton Structure in High Mountain Lakes, Research Journal of Pharmaceutical, Biological and Chemical Sciences, 7, 4, 1251-1261.

17. Krupa E. G., Barinova S. M., Romanova S. M. and Malybekov A. B., 2016b - Hydrobiological assessment of the high mountain Kolsay Lakes (Southeastern Kazakhstan) ecosystems in climatic gradient, British Journal of Environment and Climate Change, 6, 4, 259-278.

18. Kudekov T. K. (ed.), 2002 - The modern ecological state of the basin of lake Balkhash, Almaty, Kazakhstan, Kaganat, 386. (in Russian)

19. Magurran E., 1998 - Ecological diversity and its measurement, Moscow, Mir, 184. (in Russian)

20. Mazurov A. K., 2005 - Metallogenic zoning of Kazakhstan, Proceedings of Tomsk Polytechnic University, 308, 4, 33-39. (in Russian)

21. Moshkova N. A. and Gollerbach M. M., 1986 - Key to freshwater algae USSR, 10, 1, Green algae, Class Ulothrichophyceae, Moscow, 361. (in Russian)

22. Odum E., 1986 - Ecology, Moscow, Russia, World, 376. (in Russian)

23. Palamar-Mordvintseva G. M., 1982 - Key to freshwater algae USSR, 11, 2, Green algae, Class Conjugatophyceae, Desmidiaceae (2), Moscow, Russia, 621. (in Russian)

24. Penning W. E., Mjelde M., Dudley B., Hellsten S., Hanganu J., Kolada A., van den Berg M., Poikane S., Phillips G., Willby N. L. and Ecke F., 2008 - Classifying aquatic macrophytes as indicators of eutrophication in European lakes, Aquatic Ecology, 42, 237-251.

25. Ponomareva L. P., Shaukharbaeva D. S. and Lopareva T. Y., 2005 - Hydrochemical variables and phytoplankton as trophy indicators of the lake Balkhash and Ily River's reservoirs, in Fisheries research in the Republic of Kazakhstan, Almaty, Kazakhstan, Kaganat, 366-376.

26. Popova T. G., 1955 - Key to freshwater algae USSR, 7, Euglenophyta, Moscow, Russia, 213. (in Russian)

27. Protasov A. A. and Pavlyuk T. E., 2004 - Use of biodiversity indicators for assessing the state of water bodies and water quality, Hydrobiological Journal, 40, 6, 3-17.

28. Samakova A. B. (ed.), 2003 - Problems of hydroecological stability in the basin of lake 
Balkhash, Almaty, Kaganat, Kazakhstan, 584.

29. Semenova A. D. (ed.), 1977 - Guideline for chemical analysis of surface water, Leningrad, Russia, Gidrometeoizdat, 541. (in Russian)

30. Tarasov M. N., 1961 - Hydrochemistry of Balkhash Lake, Moscow, Russia, 233. (in Russian)

31. Zabelina M. M., Kiselev I. A., Proshkina-Lavrenko A. I. and Sheshukova V. S., 1951 - Key to freshwater algae USSR, 4, Diatoms, Moscow, Russia, 622. (in Russian) 